Analisis Faktor-Faktor...

\title{
ANALISIS FAKTOR-FAKTOR YANG MEMPENGARUHI PENERIMAAN PENGGUNA TERHADAP APLIKASI PERPUSTAKAAN DIGITAL: STUDI KASUS SEKOLAH TINGGI ILMU EKONOMI INDONESIA BANKING SCHOOL
}

\author{
Deni Wardani
}

\begin{abstract}
Implementation of information technology in an organization will certainly give a reaction to its users, it can be acceptance or rejection of these technology. Applications Digital Library is a facility that provides a collection of information in digital format. Indonesia Banking School implemented the Digital Library applications in early 2012. Based on user's activity data on January-June 2012, there is indication of the low acceptance of the user (use acceptance) to the digital library applications. Those makes the researchers wanted to know what are the factors that inffluence users to use digital library application.

The research design was the modification model of the Unified Theory of Acceptance and Use of Technology (UTAUT) and combined with the model Academic Discipline based Unified Theory of Acceptance and Use of Technology (ADUTAUT). Methods of data collection using questionnaires, while the data processing and decision making used Structural Equation Modelling (SEM) using Lisrel.

The result factors that affects users using digital library application are preceived of usefulness, preceived of ease of use, and preceived of faciltating condition.
\end{abstract}

Keywords: Digital Application Library, UTAUT, ADUTAUT, Structural Equation Modelling.

\section{PENDAHULUAN}

Pelayanan perpustakaan dalam suatu perguruan tinggi merupakan bagian yang penting dalam mendukung kegiatan pembelajaran pada mahasiswanya. Fasilitas perpustakaan sudah menjadi standar yang harus dimiliki oleh setiap perguruan tinggi, agar mahasiswa yang belajar dapat dengan mudah mendapatkan pengetahuan atau referensi dari perpustakaan baik berupa buku-buku, karangan ilmiah, jurnal, skripsi, karya mahasiswa dan lain-lain.

Perkembangan teknologi informasi mendorong pada bidang perpustakaan untuk menggunakan teknologi tersebut dalam rangka meningkatkan layanan kepada anggotanya. Kemajuan teknologi informasi ini dimanfaatkan dalam membangun aplikasi perpustakaan digital, agar pelayanannya menjadi meningkat, sehingga para anggotanya tidak perlu lagi datang ke ruangan perpustakaan, tetapi bisa mengakses perpustakaan digital dari mana saja sepanjang terkoneksi dengan internet. Perpustakaan digital melakukan koleksi bukubuku secara elektronik (e-book), jurnal, karya ilmiah baik tesis, skripsi, hasil seminar dan lain-lain. Banyak perpustakaan dari perguruan tinggi yang membangun dan mengimplementasikan perpustakaan digital dalam melengkapi fasilitas pelayanan kepada mahasiswanya, akan tetapi perpustakaan-perpustakaan tersebut belum dimanfaatkan 
secara maksimal oleh pengguna atau anggotanya, bahkan mulai ditinggalkan pengunjung tetapnya. Hal ini yang dimungkinkan dipengaruhi oleh beberapa faktor software yang digunakan, antara lain desain antarmuka yang kurang baik dan kemudahan penggunaannya. Penyebab lain adalah kemungkinan sedikitnya literatur atau informasi yang ditemukan oleh para pencari informasi.

Banyak perguruan tinggi yang membangun dan mengimplementasikan fasilitas layanan aplikasi perpustakaan digital secara online dengan harapan dapat membantu dan mempermudah mahasiswa dalam mencari literatur dalam kebutuhan belajarnya. Fasilitas layanan perpustakaan digital ini disosialisasikan kepada para mahasiswa dan dosen untuk memanfaatkan fasilitas tersebut pada proses belajar mengajarnya. Layanan perpustakaan digital ini menyediakan buku-buku digital (e-books), karya ilmiah, jurnal, dan lain-lain (Wahono, 1998) dengan harapan dapat digunakan dengan sebaik-baiknya dalam membantu proses belajar-mengajar dikelas. Dari beberapa fakta memperlihatkan rendahnya pengguna yang mengakses aplikasi perpustakaan digital. Rendahnya pengaksesan perpustakaan digital dapat disebabkan oleh masih sedikit keinginan pengguna dalam mengakses aplikasi perpustakaan digital, kurangnya budaya membaca dari pengguna, layanan aplikasi kurang memadai, kurangnya sumber referensi digital.

Perpustakaan digital yang telah diimplementasikan tidak dimanfaatkan secara optimal oleh pengguna. Selain itu, setelah wawancara dengan beberapa petugas perpustakaan sebagai operator mengatakan bahwa aplikasi perpustakaan digital tersebut masih ada kekurangannya yang kadang terjadi diantaranya: tampilan data biliograpi kadang hilang, kode barkode pada tampilan buku tertentu tidak muncul, kadang data yang disimpan tidak masuk database, gambar sampul buku berubah sendiri, dan lain-lain. Oleh karena itu, paper ini akan membahas mengenai faktor-faktor apa saja yang mempengaruhi penerimaan pengguna terhadap aplikasi perpustakaan digital.

Tujuan yang ingin dicapai dalam penelitian ini adalah :

1. Melakukan analisis terhadap penerapan aplikasi perpustakaan digital yang sudah ada berupa banyaknya pengguna yang mengakses.

2. Mendapatkan faktor-faktor yang dapat mempengaruhi pengguna untuk menggunakan aplikasi perpustakaan digital.

3. Memberikan saran kepada penyelenggara aplikasi perpustakaan digital mengenai faktor penghambat dan pendukung penerimaan penggunaan aplikasi perpustakaan digital.

\section{TINJAUAN TEORITIS}

Perpustakaan digital merupakan suatu organisasi yang menyimpan data baik itu buku (tulisan), gambar, suara dalam bentuk file elektronik dan mendistribusikannya dengan menggunakan protokol elektronik melalui jaringan komputer (Wahono, 1998). Perpustakaan digital menandakan bahwa koleksinya berbentuk digital dan dapat saja tidak mempunyai koleksi cetakannya. Perpustakaan digital mungkin dapat diakses melalui internet atau hanya tersedia di jaringan lokal. Berdasarkan definisi di atas, maka pada perpustakaan digital terdapat karakteristik sebagai berikut (Sulistyo, 1991):

a. Perpustakaan digital merupakan maujud (entity) tunggal. 
Analisis Faktor-Faktor...

b. Perpustakaan digital memerlukan teknologi komunikasi dan informasi ke sumber yang tersebar di berbagai tempat.

c. Kaitan antara berbagai perpustakaan digital bersifat transparan bagi pemakai bertujuan akses universal terhadap perpustakaan digital dan jasa informasi.

d. Koleksi perpustakaan digital tidak terbatas pada surogat (pengganti) dokumen, melainkan ke artefak digital yang tidak dapat diwakili atau diwujudkan atau didistribusikan dalam format tercetak.

Venkatesh dan kawan-kawan mengembangkan dan merumuskan model penerimaan penggunaan teknologi pada tahun 2003 dengan nama Unified Theory of Acceptance and Use of Technology (UTAUT). Pengembangan model UTAUT oleh Venkatesh ini melalui tinjauan dan review dari penggabungan delapan model penelitian sebelumnya yang telah digunakan untuk menjelaskan perilaku pengguna Teknologi Informasi yaitu (Theory of Reasoned Action, Technology Acceptance model, Motivational Model, Theory of Planned Behavior, A Combined Theory of Planned Behavior/ Technology Acceptance Model, dan Sosial Cognitive Theory) (Venkatesh et. al., 2003).

Model UTAUT bertujuan untuk menjelaskan maksud pengguna dalam menggunakan Teknologi Informasi dan menggambarkan perilaku pengguna berikutnya. Model UTAUT terbukti dapat menjelaskan hingga $70 \%$ varian penerimaan pengguna (Venkatesh et. al., 2003). Model UTAUT pada dasarnya sama dengan model TAM yang perubahannya ditambahkan dengan dua komponen, yaitu pengaruh sosial (social influence) dan kondisi fasilitas pendukung (facilitating condition) (Hakim, 2001).

Model UTAUT memperlihatkan faktor-faktor ekternal yang mempengaruhi penerimaan suatu teknologi lebih jelas karena sudah lebih spesifik. Menurut Venkatesh (2003) variabel behavioral intention akan dipengaruhi oleh variabel performance expectancy, effort expectancy, dan social influence. Hubungan antara variabel performance expectancy, effort expectancy, dan social influence dengan behavioral intention tersebut akan dipengaruhi oleh moderator variabel gender dan Age. Jadi maksudnya bahwa variabel harapan kinerja (performance expectancy) mempengaruhi keinginan dari kebiasaan penggunaan teknologi (Behavioral intention) dan faktor ini dipengaruhi oleh faktor pengontrol yaitu jenis kelamin (gender) dan usia (age), maka harapan kinerja pengaruhnya akan berbeda untuk kalangan jenis kelamin dan usia. Hal ini berlaku juga untuk faktor-faktor ekternal yang lainnya seperti effort expectancy, social influence, dan facilitating condition yaitu hubungan antara effort expectancy, dan social influence dengan behavioral intention akan dipengaruhi oleh experience, dan voluntariness of use juga ikut berpengaruh terhadap hubungan antara social influence dengan behavioral intention. Kemudian variabel use behavior akan dipengaruhi oleh behavioral intention dan facilitating condition, dengan moderate variable age dan experience yang mempengaruhi hubungan antara use behavior dengan facilitating condition.

Harapan kinerja (performance expectancy) didefinisikan sebagai derajat dimana seseorang percaya bahwa dengan menggunakan sistem akan membantu meningkatkan performa atau kinerja pekerjaannya. Effort Expectancy didefinisikan sebagai derajat kemudahan dalam penggunaan sistem. Social influence didefinisikan sebagai derajat dimana seseorang merasa bahwa dia itu seharusnya menggunakan sistem yang baru karena orang yang penting baginya percaya akan hal tersebut. Facilitating Condition 
didefinisikan sebagai derajat dimana seseorang percaya bahwa organisasi dan infrastruktur teknis tersedia untuk mendukung penggunaan sistem. (Venkatesh et. al., 2003).

Jenis kelamin (Gender) dimasukkan sebagai moderating variable, karena penelitian mengenai perbedaan gender mengindikasikan bahwa laki-laki cenderung lebih taskoriented dibandingkan perempuan (Minton and Schneider, 1980). Oleh karena itu, performance expectancy, yang fokus pada penyelesaian pekerjaan, lebih menonjol pada laki-laki. Sedangkan pada wanita yang lebih menonjol adalah effort expectancy (Venkatesh et. al., 2003). Usia (Age) secara teori memiliki peran sebagai moderating variable. Age dianggap mempunyai efek pada sikap (attitude), dimana efek tersebut akan lebih kuat bagi pekerja yang lebih muda. (Venkatesh et. al., 2003). Pengalaman (experience) termasuk sebagai variabel moderator.

Pengaruh effort expectancy dan social influence terhadap behavioral intention akan kuat pada awal pengalaman (experience) pemakaian sistem. Begitu juga dengan pengaruh facilitating condition pada pemakaian (usage) akan dipengaruhi experience, yakni efek akan semakin kuat dengan meningkatnya experience (Venkatesh et. al., 2003). Penggunaan secara sukarela (voluntariness) yaitu apakah sistem yang digunakan secara sukarela atau merupakan suatu keharusan. Variabel moderator ini akan mempengaruhi social infuence jika dalam keadaan mandatory pada awal pemakaian sistem. (Venkatesh et.al., 2003). Behaviora Intention didefinisikan sebagai ukuran seseorang menggunakan aplikasi/ sistem. Use Behavior didefinisikan sebagai ukuran penerimaan teknologi.

Academic Discipline base Unified Theory of Acceptance and Use of Technology (ADUTAUT) merupakan model penerimaaan teknologi yang dikembangkan oleh Orji (2010) berdasarkan dari model UTAUT yang dikembangkan oleh Venkatesh (2003) dengan menambahkan moderating variable disiplin akademik (academic discipline). Orji melakukan penelitian mengenai dampak disiplin akademik terhadap penerimaan teknologi informasi. Maka berdasarkan hasil penelitian tersebut dapat disimpulkan bahwa perbedaan disiplin akademik akan memiliki pengaruh yang berbeda terhadap penerimaan pengguna Teknologi Informasi (Orji, 2010).

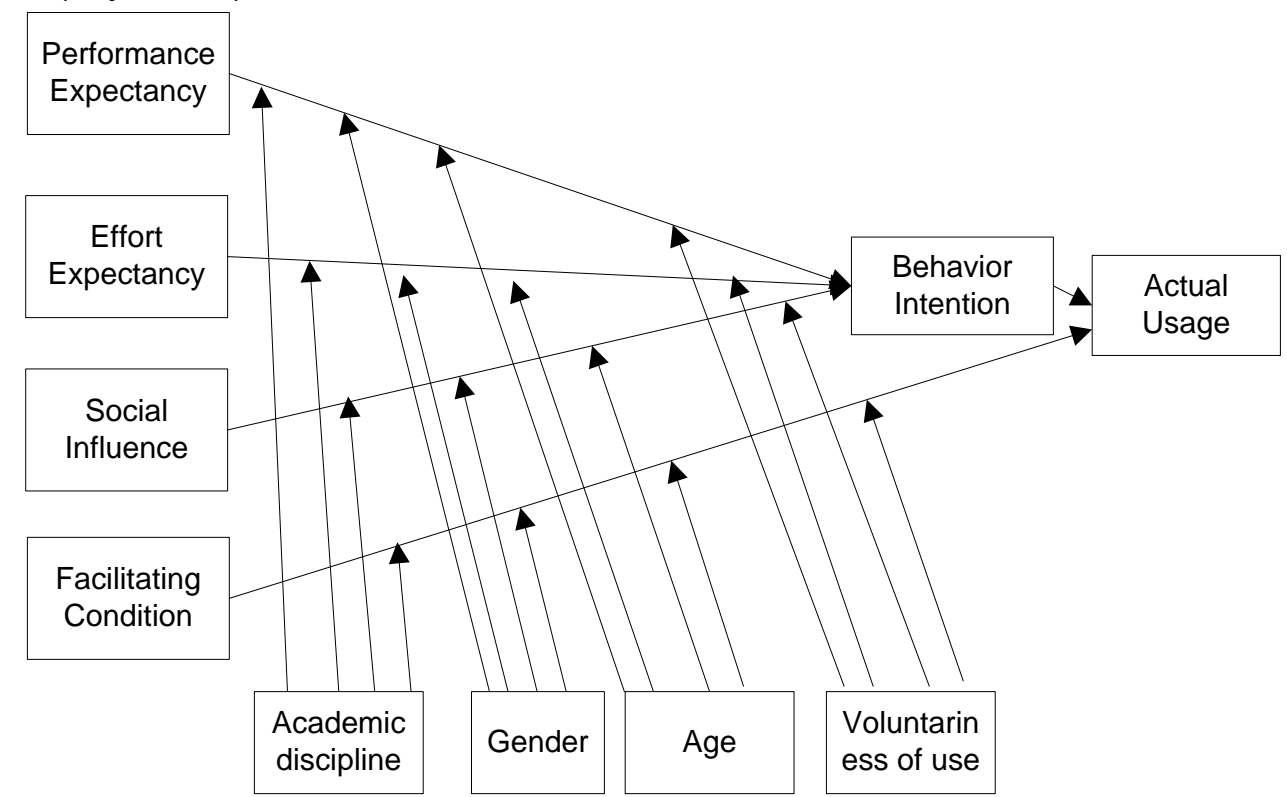

Gambar 1. Model ADUTAUT (Orji, 2010) 
Analisis Faktor-Faktor...

SEM (structural equation modeling) merupakan suatu teknik statistik yang menganalisis multivariat yang digunakan untuk membangun dan menguji model statistik yang biasanya dalam bentuk model-model sebab akibat. SEM merupakan teknik hibrida yang meliputi aspek-aspek penegasan (confirmatory) dari analisis faktor, analisis jalur dan regresi yang dapat dianggap sebagai kasus dalam SEM.

Pada SEM terdapat prosedur atau tahapan-tahapan yang umumnya sebagai berikut: (Bollen dan Log, 1993)

1. Spesifikasi model (model specification)

Pada tahap ini model awal ini diformulasikan berdasarkan suatu teori atau penelitian sebelumnya. Spesifikasi model penelitian, yang merepresentasikan permasalahan yang diteliti adalah penting dalam SEM. Hoyle (1998) mengatakan bahwa analisis tidak akan dimulai sampai peneliti menspesifikasikan sebuah model yang menunjukkan hubungan di antara variabel-variabel yang akan dianalisis. Melalui langkah-langkah di bawah ini, peneliti dapat memperoleh model yang diinginkan, langkah-langkah tersebut adalah:

a. Spesifikasi model pengukuran

b. Spesifikasi model struktural

c. Gambar Path Diagram dari model hybrid yang merupakan kombinasi model pengukuran dan struktural.

2. Identifikasi (identification)

Tahap merupakan pengkajian mengenai kemungkinan diperolehnya nilai yang unik untuk setiap parameter yang ada di dalam model dan kemungkinan persamaan simultan tidak ada solusinya. Secara garis besar ada 3 kategori identifikasi dalam persamaan simultan yaitu:

- Under-Identified model adalah model dengan jumlah parameter yang diestimasi lebih besar dari jumlah data yang diketahui.

- Just-Identified model adalah model dengan jumlah parameter yang diestimasi sama dengan data yang diketahui.

- Over-Identified model adalah model dengan jumlah parameter yang diestimasi lebih kecil dari jumlah data yang diketahui.

3. Estimasi (estimation)

Tahap ini berkaitan dengan estimasi terhadap model untuk menghasilkan nilai-nilai parameter dengan menggunakan salah satu metode estimasi yang tersedia. Dalam melakukan estimasi kita berusaha memperoleh nilai parameter-parameter sehingga matrik kovarian yang diturunkan dari model akan sedekat mungkin atau sama dengan matrik kovarian populasi dari variabel-variabel teramati. Beberapa jenis fungsi yang diminimalisasikan $F$, ini berkaitan dengan estimator yang digunakan yaitu: Instrument Variable (IV), Two Stage Least Square (TSLS), Unweighted Least Square (ULS), Generalize Least Square (GLS), Maximum Likelihood (ML), Weighted Least Square (WLS), Diagonally Weighted Least Square (DWLS).

4. Uji kecocokan (testing fit)

Tahap ini berkaitan dengan pengujian kecocokan antara model dengan data, validitas, dan reliabilitas model pengukuran, dan signifikasi koefisien-koefisien dari model struktural. Beberapa kriteria ukuran kecocokan atau Goodness Of Fit (GOF) 
dapat digunakan untuk melaksanakan langkah ini. Menurut Hair et. al. (1998) evaluasi terhadap tingkat kecocokan data dengan model dilakukan melalui beberapa tahapan, yaitu:

a) Kecocokan keseluruhan model (overall model fit)

Tahap pertama uji kecocokan ditujukan untuk mengevaluasi derajat kecocokan atau Goodness Of Fit (GOF) antara data dengan model. SEM tidak mempunyai satu uji statistik terbaik yang dapat menjelaskan "kekuatan" prediksi model. Sebagai gantinya para peneliti telah mengembangkan beberapa ukuran GOF atau Goodness Of Fit Indices (GOFI) yang dapat digunakan secara bersamasama atau kombinasi. Hair et. al. (1998) mengelompokkan GOFI yang ada menjadi 3 bagian yaitu:

- absolute fit measures (ukuran kecocokan absolut)

- incremental fit measures (ukuran kecocokan inkremental)

- parsimonious fit measures (ukuran kecocokan parsimoni).

b) Kecocokan model pengukuran (measurement model fit)

Evaluasi ini akan dilakukan terhadap setiap konstruk atau model pengukuran (hubungan antara sebuah variabel laten dengan beberapa variabel teramati/indikator) secara terpisah melalui:

a) Evaluasi terhadap validitas (validity) dari model pengukuran

Validitas berhubungan dengan apakah suatu variabel mengukur apa yang seharusnya diukur. Rigdon dan Ferguson (1991) dan Doll, Xia, Torkzadeh (1994) mengatakan bahwa suatu variabel dikatakan mempunyai validitas yang baik terhadap konstruk atau variabel latennya jika:

- Nilai t muatan faktornya (loading factors) lebih besar dari nilai kritis (atau $\geq 1.96$ atau untuk praktisnya $\geq 2$ )

- $\quad$ Muatan faktor standarnya (standardized loading factors) $\geq 0.70$.

Sementara itu peneliti lain yaitu Igbraria et. al. (1997) yang menggunakan guidelines dari Hair et. al. (1995) tentang relative importance and significant of the factor loading of each item, menyatakan bahwa muatan faktor standar $\geq 0.50$ adalah very significant.

b) Evaluasi terhadap reliabilitas (reliability) dari model pengukuran

Reliabilitas merupakan konsistensi suatu pengukuran. Pengukuran reliabilitas dalam SEM akan digunakan: composite reliability measure (ukuran reliabilitas komposit) dan variance extracted measure (ukuran ekstrak varian). Reliabilitas komposit suatu konstruk dihitung sebagai:

$$
\text { Construct Reliability }=\frac{\left(\sum \text { std.loading }\right)^{2}}{\left(\sum \text { std.loading }\right)^{2}+\sum e_{j}}
$$

Dari rumus tersebut, std. loading (standardized loadings) dapat diperoleh secara langsung dari keluaran program $L I S R E L$, dan $e_{j}$ adalah measurement error untuk setiap indikator atau variabel teramati (Fornel dan Larker, 1981). Ukuran ekstrak varian dapat dihitung sebagai berikut (Fornel dan Larker, 1981): 


$$
\text { Variance Extracted }=\frac{\sum \text { std. } \text { loading }^{2}}{\sum s t d . \text { loading }^{2}+\sum e_{j}}
$$

Atau (Hair et. al. 2007):

$$
\text { Variance Extracted }=\frac{\sum \text { std. } \text { loading }^{2}}{N}
$$

Dimana $\mathrm{N}$ adalah banyaknya variabel teramati dari model pengukuran. Hair et. al. (1998), menyatakan bahwa sebuah konstruk mempunyai reliabilitas yang baik adalah jika:

- Nilai Construct Reliability (CR)-nya $\geq 0.70$, dan

- Nilai Variance Extracted (VE)-nya $\geq 0.50$

c) Kecocokan model struktural (structural model fit)

Pada tahap uji kecocokan ini dilakukan terhadap signifikasi koefisien dalam persamaan struktural dengan menspesifikasi tingkat signifikasi $\alpha=0.05$, maka nilai t dari persamaan harus $>1.96$. Selain itu, perlu dilakukan evaluasi terhadap solusi standar dimana semua koefisien mempunyai varian dengan nilai maksimumnya 1.

5. Respesifikasi (respecification)

Pelaksanaan respesifikasi sangat tergantung kepada strategi pemodelan yang akan digunakan. Strategi pemodelan yang dapat dipilih dalam SEM ada 3 jenis, yaitu:

1) Strategi pemodelan konfirmatori atau confirmatory modeling strategy (Hair et. al.,1998) atau strictly confirmatory/SC (Joreskog dan Sorbom, 1996). Pada strategi pemodelan ini diformulasikan atau dispesifikasikan satu model tunggal, kemudian dilakukan pengumpulan data empiris untuk diuji signifikasinya.

2) Strategi kompetisi model atau competing models strategy (Hair et. al., 1998) atau alternative/competing models/AM (Joreskog dan Sorbom, 1996). Pada strategi pemodelan ini beberapa model alternatif dispesifikasikan dan berdasarkan analisis terhadap satu kelompok data empiris dipilih salah satu model yang paling sesuai.

\section{METODE PENELITIAN}

\subsection{Pengumpulan Data Awal}

Studi kasus objek penelitian ini yaitu suatu perguruan tinggi yang bernama Sekolah Tinggi Ilmu Ekonomi Indonesia Banking School dengan mengumpulkan data awal dengan cara wawancara terhadap bagian perpustakaan yang mengelola aplikasi perpustakaan digital. Kemudian penentuan tujuan dari penelitian yang akan dilakukan.

\subsection{Studi Literatur}

Studi literatur dilakukan untuk mendapatkan model dari teori sebelumnya. 


\subsection{Desain Penelitian}

Desain penelitian disusun berdasarkan model yang ada, kemudian disesuaikan dengan kebutuhan dari penelitian ini. Model penelitian ini berdasarkan studi literatur pada penelitian terdahulu dengan model penelitian seperti gambar 2 berikut.

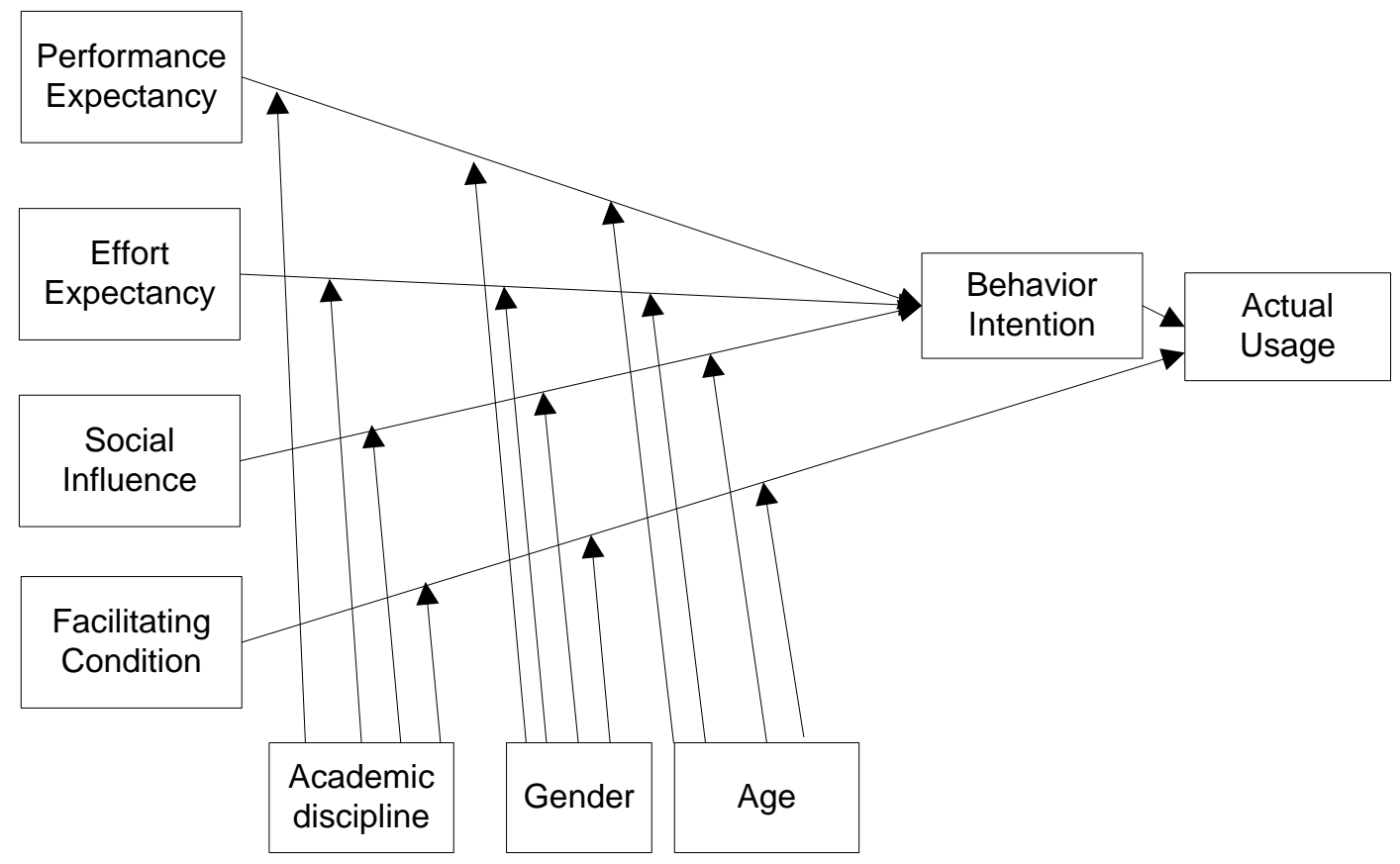

Gambar 2. Model penelitian yang dilakukan

\subsection{Pembuatan Hipotesis}

Setelah model penelitian terbentuk, kemudian dilakukan pembuatan hipotesis dari model penelitian ini sebagai bahan untuk pembuktian apakah hipotesis tersebut diterima atau ditolak setelah pengolahan hasil dari pengumpulan dan mendapatkan data empiris.

\subsection{Pembuatan Kuesioner}

Perancangan kuesioner dilakukan dengan mengadopsi kuesioner dari penelitian terdahulu yang telah dilakukan oleh peneliti morteza (2011) dengan jumlah 21 variabel teramati yang terdiri dari 4 variabel teramati reflektif pada variabel laten Performance expectancy $(\mathrm{PE})$, Effort expectancy (EE), Social influence (SI), Facilitating condition (FC), dan 2 variabel teramati pada variabel laten Behaviour Influence (BI), dan Actual Usage (AU).

\subsection{Pengumpulan Data}

Pengumpulan data dilakukan dengan menggunakan kuesioner yang telah dibuat sesuai dengan desain penelitian.

\subsection{Pengolahan Data dan Uji hipotesis}

Setelah dilakukan pengolahan data dengan menggunakan metode SEM untuk menguji hipotesis yang sudah didefinisikan di awal apakah hipotesis tersebut diterima atau ditolak. 
Analisis Faktor-Faktor...

\subsection{Analisis Data}

Analisis data dilakukan untuk menentukan faktor-faktor apa saja yang mempengaruhi penerimaan terhadap penerapan aplikasi perpustakaan digital, sehingga hasil tersebut dapat dijadikan bahan acuan dan pertimbangan dalam menentukan saran perbaikan bagi pengelola aplikasi perpustakaan digital.

\subsection{Kesimpulan}

Pada langkah ini dilakukan penarikan kesimpulan dengan mengacu kepada hasil dari analisis data.

\section{HASIL PENELITIAN DAN PEMBAHASAN}

\subsection{Hasil Penelitian}

Untuk dapat mengetahui faktor-faktor apa saja yang mempengaruhi penerimaan pengguna terhadap aplikasi perpustakaan digital, maka penulis melakukan studi kasus ke salah satu perguruan tinggi yang telah mengimplementasikan dan mengoperasikan aplikasi perpustakaan digital ini lebih dari satu tahun. Pada studi kasus ini dilakukan melalui metode pengumpulan data dengan penyebaran kuesioner kepada responden yang berisi pertanyaan-pertanyaan berdasarkan faktor-faktor pada model ADUTAUT.

Daftar pertanyaan yang diberikan berkaitan dengan tahapan pelaksanaan yang akan dilakukan dalam analisis dalam menentukan analisis faktor-faktor penerimaan pengguna terhadap aplikasi perpustakaan digital. Kuesioner dibuat berdasarkan pada faktor-faktor yang ada pada model penelitian awal yang dibangun. Setiap faktor diterjemahkan menjadi beberapa pertanyaan yang akan dijawab oleh para responden. Responden akan diminta menjawab pertanyaan berdasarkan skala likert 1 - 5 dengan nilai terendah dari skala likert ini adalah sangat setuju dan yang tertinggi sangat tidak setuju. Responden yang diminta untuk mengisi kuesioner adalah para pengguna dari aplikasi perpustakaan digital pada objek studi kasus.

Responden dari studi kasus ini adalah para mahasiswa dan dosen dari semua jurusan sebagai pengguna dari aplikasi perpustakaan digital yaitu jurusan manajemen dan akuntansi. Pada studi kasus ini terdapat 185 responden yang mengisi kuesioner mengenai penerimaan pengguna terhadap aplikasi perpustakaan digital yang terdiri dari 86 responden jurusan manajemen dan 99 responden dari jurusan akuntansi.

Pada penentuan responden menggunakan menggunakan metode stratified random sampling secara porposional dengan pembagian responden dari jurusan manajemen dan akuntansi. Stratified random sampling merupakan teknik pengambilan sampel secara porposional dari tiap-tiap bagian dari sampel. Teknik stratified diambil penulis untuk mengetahui hasil penelitian dari masing-masing jurusan secara porposional.

Dari hasil output program Lisre/ terlihat bahwa nilai degree of freedom sebesar 178. Hal ini menunjukkan bahwa model ini termasuk model yang over-identified ( $\mathrm{df}>0$ ), maka kemudian dapat dilakukan tahap berikutnya yaitu estimasi model.

Penelitian ini menggunakan metode estimasi Maximum Likelihood, dengan alasan bahwa metode ini merupakan metode yang banyak digunakan peneliti dalam SEM pada saat sekarang ini (Wijanto, 2008). Jumlah perbandingan responden yang dibutuhkan untuk ML paling sedikit adalah 5 responden per variabel teramati. Pada penelitian ini memiliki 21 
variabel teramati, sehingga data yang dibutuhkan paling sedikit adalah 105 responden. Jumlah data responden pada penelitian ini sebesar 185 responden, maka dalam jumlah data yang dibutuhkan sudah mencukupi untuk metode MLE (Maximum Likelihood Estimator).

Hasil dari uji normal menunjukkan bahwa data tidak terdistribusi normal, hal ini ditunjukkan dari nilai Z-Score Skewness dan Kurtosis pada bagian Test of Multivariate Normality for Continous Variables. Pada tingkat kepercayaan 99\%, yang berarti tingkat signifikasi sebesar 1\%, nilai dari Z-Score untuk Skewness dan Kurtosis untuk sebuah distribusi normal adalah \pm 2.58 . Jadi, jika angka Skewness atau Kurtosis berada di luar range tersebut, distribusi dapat dikatakan tidak normal(Santoso, 2011). Nilai uji skor normal, nilai Skewness dan Kurtosis masing-masing adalah 22.390 dan 11.598 sehingga dapat disimpulkan bahwa data tidak terdistribusi normal. Untuk mengestimasi data yang tidak terdistribusi normal menggunakan metode $\mathrm{ML}$, maka perlu ditambahkan asymptotic covariance matrix.

Secara umum, hasil analisis penelitian ini dapat dilihat pada tabel 1. Hasil analisis ini direkap berdasarkan besarnya pengaruh faktor-faktor ADUTAUT penerimaan pengguna terhadap aplikasi perpustakaan digital.

Tabel 1. Evaluasi Model Struktural Model Penerimaan Umum

\begin{tabular}{|l|l|l|l|l|}
\hline Hipotesis & path & Estimasi & Nilai-t & Kesimpulan \\
\hline 1 & $\mathrm{PE} \rightarrow \mathrm{BI}$ & 0.31 & 3.34 & Signifikan (H1 diterima) \\
\hline 2 & $\mathrm{EE} \rightarrow \mathrm{BI}$ & 0.47 & 5.45 & Signifikan (H2 diterima) \\
\hline 3 & $\mathrm{SI} \rightarrow \mathrm{BI}$ & -0.02 & -0.30 & Signifikan (H3 ditolak) \\
\hline 4 & $\mathrm{FC} \rightarrow \mathrm{AU}$ & 0.15 & 1.99 & Signifikan (H4 diterima) \\
\hline 5 & $\mathrm{BI} \rightarrow \mathrm{AU}$ & 0.57 & 7.63 & Signifikan (H5 diterima) \\
\hline
\end{tabular}

Dari tabel di atas terlihat bahwa hasil dari model penerimaan secara umum dapat dilihat bahwa konstruk SI tidak memiliki pengaruh yang signifikan terhadap konstruk BI. Pada hubungan PE terhadap BI sebesar 0.31 yang berarti konstruk PE memiliki pengaruh sebesar $31 \%$ terhadap BI. Pada hubungan EE terhadap BI sebesar 0.47 , yang berarti konstruk EE memiliki pengaruh sebesar 47\% terhadap BI. Konstruk FC mempengaruhi konstruk AU dengan kontribusi sebesar $15 \%$. Konstruk AU dipengaruhi oleh konstruk BI dengan kontribusi sebesar $57 \%$.

Hasil dari model penerimaan jurusan manajemen dapat dilihat pada tabel 2 berikut. 
Analisis Faktor-Faktor...

Tabel 2. Tabel Hipotesis Penerimaan Jurusan Manajemen

\begin{tabular}{|l|l|l|l|l|}
\hline hipotesis & path & Estimasi & Nilai-t & Kesimpulan \\
\hline 1 & $\mathrm{PE} \rightarrow \mathrm{BI}$ & 0.28 & 2.20 & Signifikan (H1 diterima) \\
\hline 2 & $\mathrm{EE} \rightarrow \mathrm{BI}$ & 0.57 & 4.43 & Signifikan (H2 diterima) \\
\hline 3 & $\mathrm{SI} \rightarrow \mathrm{BI}$ & 0.06 & 0.67 & Signifikan (H3 ditolak) \\
\hline 4 & $\mathrm{FC} \rightarrow \mathrm{AU}$ & 0.29 & 1.53 & Signifikan (H4 ditolak) \\
\hline 5 & $\mathrm{BI} \rightarrow \mathrm{AU}$ & 0.52 & 2.86 & Signifikan (H5 diterima) \\
\hline
\end{tabular}

Untuk model penerimaan jurusan manajemen memperlihatkan bahwa konstruk SI tidak memiliki pengaruh yang signifikan terhadap konstruk BI dan konstruk FC tidak berpengaruh terhadap konstruk AU. Pada hubungan PE dan EE terhadap BI sebesar 0.28 dan 0.57, yang berarti konstruk PE memiliki pengaruh sebesar $28 \%$ terhadap $\mathrm{BI}$ dan EE mempengaruhi BI sebesar 57\%. Konstruk AU dipengaruhi oleh konstruk BI dengan kontribusi sebesar 52\%. Hasil dari model penerimaan jurusan Akuntansi dapat dilihat pada tabel 3 berikut.

Tabel 3. Hipotesis Penerimaan Jurusan Akuntansi

\begin{tabular}{|l|l|c|c|l|}
\hline hipotesis & path & Estimasi & Nilai-t & Kesimpulan \\
\hline 1 & $\mathrm{PE} \rightarrow \mathrm{BI}$ & 0.34 & 2.69 & Signifikan $(\mathrm{H} 1$ diterima $)$ \\
\hline 2 & $\mathrm{EE} \rightarrow \mathrm{BI}$ & 0.28 & 2.31 & Signifikan $(\mathrm{H} 2$ diterima $)$ \\
\hline 3 & $\mathrm{SI} \rightarrow \mathrm{BI}$ & -0.01 & -0.08 & Signifikan $(\mathrm{H}$ 3 ditolak $)$ \\
\hline 4 & $\mathrm{FC} \rightarrow \mathrm{AU}$ & 0.26 & -0.0 & Signifikan $(\mathrm{H} 4$ ditolak $)$ \\
\hline 5 & $\mathrm{BI} \rightarrow \mathrm{AU}$ & 0.63 & 5.69 & Signifikan $(\mathrm{H} 5$ diterima $)$ \\
\hline
\end{tabular}

Untuk model penerimaan jurusan Akuntansi memperlihatkan bahwa konstruk SI tidak memiliki pengaruh yang signifikan terhadap konstruk $\mathrm{BI}$ dan konstruk FC tidak memiliki pengaruh yang signifikan terhadap konstruk AU. Pada hubungan PE terhadap BI sebesar 0.34, yang berarti konstruk PE memiliki pengaruh sebesar $34 \%$ terhadap BI. Pada hipotesis 2 diterima dengan nilai koefisien hubungan EE terhadap $\mathrm{BI}$ sebesar 0.28 , yang berarti konstruk EE memiliki pengaruh sebesar 28\% terhadap BI. Konstruk BI berkontribusi mempengaruhi konstruk AU sebesar $63 \%$.

Hasil dari model penerimaan jenis kelamin laki-laki dapat dilihat pada tabel 4 berikut.

Tabel 4. Hipotesis penerimaan Laki-laki

\begin{tabular}{|l|l|l|l|l|}
\hline Hipotesis & path & Estimasi & Nilai-t & Kesimpulan \\
\hline 1 & $\mathrm{PE} \rightarrow \mathrm{BI}$ & 0.29 & 2.17 & Signifikan $(\mathrm{H} 1$ diterima $)$ \\
\hline 2 & $\mathrm{EE} \rightarrow \mathrm{BI}$ & 0.55 & 4.52 & Signifikan $(\mathrm{H} 2$ diterima $)$ \\
\hline 3 & $\mathrm{SI} \rightarrow \mathrm{BI}$ & -0.07 & -0.79 & Signifikan $(\mathrm{H}$ 3 ditolak $)$ \\
\hline 4 & $\mathrm{FC} \rightarrow \mathrm{AU}$ & -0.02 & -0.15 & Signifikan $(\mathrm{H} 4$ ditolak $)$ \\
\hline 5 & $\mathrm{BI} \rightarrow \mathrm{AU}$ & 0.63 & 3.75 & Signifikan $(\mathrm{H} 5$ diterima $)$ \\
\hline
\end{tabular}

Untuk model penerimaan jenis kelamin laki-laki memperlihatkan bahwa konstruk SI tidak memiliki pengaruh yang signifikan terhadap konstruk BI dan konstruk FC tidak memiliki pengaruh yang signifikan terhadap konstruk AU. Pada hubungan PE terhadap BI sebesar 
0.29 yang berarti konstruk berkontribusi mempengaruhi konstruk $\mathrm{Bl}$ sebesar $29 \%$. Kemudian hubungan EE terhadap $\mathrm{BI}$ sebesar 0.55 yang berarti konstruk berkontribusi mempengaruhi konstruk $\mathrm{BI}$ sebesar $55 \%$. Konstruk AU dipengaruhi oleh konstruk BI dengan kontribusi sebesar $63 \%$.

Hasil model penerimaan jenis kelamin perempuan dapat dilihat pada tabel 5 berikut.

Tabel 5. Tabel Hipotesis pengguna perempuan

\begin{tabular}{|l|l|l|l|l|}
\hline Hipotesis & path & Estimasi & Nilai-t & Kesimpulan \\
\hline 1 & $\mathrm{PE} \rightarrow \mathrm{BI}$ & 0.42 & 3.17 & Signifikan $(\mathrm{H} 1$ diterima) \\
\hline 2 & $\mathrm{EE} \rightarrow \mathrm{BI}$ & 0.31 & 2.60 & Signifikan $(\mathrm{H} 2$ diterima) \\
\hline 3 & $\mathrm{SI} \rightarrow \mathrm{BI}$ & 0.09 & 1.04 & Signifikan $(\mathrm{H}$ 3 ditolak) \\
\hline 4 & $\mathrm{FC} \rightarrow \mathrm{AU}$ & 0.39 & 2.31 & Signifikan $(\mathrm{H} 4$ diterima) \\
\hline 5 & $\mathrm{BI} \rightarrow \mathrm{AU}$ & 0.33 & 2.22 & Signifikan $(\mathrm{H} 5$ diterima) \\
\hline
\end{tabular}

Untuk model penerimaan jenis kelamin perempuan memperlihatkan bahwa konstruk SI tidak memiliki pengaruh yang signifikan terhadap konstruk BI. Pada hubungan PE terhadap $\mathrm{BI}$ sebesar 0.42 , yang berarti konstruk berkontribusi mempengaruhi konstruk BI sebesar $42 \%$. Pada hubungan EE terhadap BI sebesar 0.31 , yang berarti konstruk berkontribusi mempengaruhi konstruk BI sebesar 31\%. Pada hubungan FC terhadap BI sebesar 0.39, yang berarti konstruk berkontribusi mempengaruhi konstruk BI sebesar $39 \%$. Konstruk AU dipengaruhi oleh konstruk BI dengan kontribusi sebesar 33\%.

Hasil dari model penerimaan usia di bawah 25 tahun dapat dilihat pada tabel 6 berikut.

Tabel 6. Tabel Hipotesis Penerimaan Pengguna di bawah usia 25 tahun

\begin{tabular}{|l|l|l|l|l|}
\hline Hipotesis & path & Estimasi & Nilai-t & Kesimpulan \\
\hline 1 & $\mathrm{PE} \rightarrow \mathrm{BI}$ & 0.29 & 2.33 & Signifikan $(\mathrm{H} 1$ diterima) \\
\hline 2 & $\mathrm{EE} \rightarrow \mathrm{BI}$ & 0.49 & 4.05 & Signifikan $(\mathrm{H} 2$ diterima) \\
\hline 3 & $\mathrm{SI} \rightarrow \mathrm{BI}$ & 0.02 & -0.46 & Signifikan $(\mathrm{H}$ 3 ditolak) \\
\hline 4 & $\mathrm{FC} \rightarrow \mathrm{AU}$ & 0.29 & 2.76 & Signifikan $(\mathrm{H} 4$ diterima) \\
\hline 5 & $\mathrm{BI} \rightarrow \mathrm{AU}$ & 0.52 & 4.80 & Signifikan $(\mathrm{H} 5$ diterima) \\
\hline
\end{tabular}

Untuk model penerimaan usia di bawah 25 tahun memperlihatkan bahwa konstruk SI tidak memiliki pengaruh yang signifikan terhadap konstruk BI. Pada hubungan PE terhadap $\mathrm{BI}$ sebesar 0.29, yang berarti konstruk berkontribusi mempengaruhi konstruk BI sebesar 29\% dan EE berpengaruh terhadap BI sebesar 49\%.. Selain itu Konstruk FC (Facilitation Condition) mempengaruhi AU sebesar 29\%. Konstruk AU dipengaruhi oleh konstruk BI dengan kontribusi sebesar $52 \%$.

Hasil dari model penerimaan usia di atas 25 tahun dapat dilihat pada tabel 7 berikut. 
Analisis Faktor-Faktor...

Tabel 7. Kesimpulan Hipotesis pengguna diatas 25 tahun

\begin{tabular}{|l|l|l|l|l|}
\hline hipotesis & path & Estimasi & Nilai-t & Kesimpulan \\
\hline 1 & $\mathrm{PE} \rightarrow \mathrm{BI}$ & 0.33 & 2.24 & Signifikan $(\mathrm{H} 1$ diterima $)$ \\
\hline 2 & $\mathrm{EE} \rightarrow \mathrm{BI}$ & 0.30 & 2.65 & Signifikan $(\mathrm{H} 2$ diterima $)$ \\
\hline 3 & $\mathrm{SI} \rightarrow \mathrm{BI}$ & 0.05 & 0.46 & Signifikan (H3 ditolak) \\
\hline 4 & $\mathrm{FC} \rightarrow \mathrm{AU}$ & 0.2 & 1.24 & Signifikan (H4 ditolak) \\
\hline 5 & $\mathrm{BI} \rightarrow \mathrm{AU}$ & 0.57 & 4.20 & Signifikan $(\mathrm{H} 5$ diterima) \\
\hline
\end{tabular}

Untuk model penerimaan usia di atas 25 tahun memperlihatkan bahwa konstruk SI dan FC tidak memiliki pengaruh yang signifikan terhadap konstruk $\mathrm{BI}$ dan FC. Pada hubungan PE terhadap $\mathrm{BI}$ sebesar 0.33, yang berarti konstruk berkontribusi mempengaruhi konstruk $\mathrm{BI}$ sebesar 33\%. Konstruk BI mempengaruhi konstruk AU dengan kontribusi sebesar 57\%.

\subsection{Pembahasan}

Pada model penerimaan umum secara keseluruhanan, hanya ada satu hipotesis yang ditolak, yaitu hipotesis 3. Hal ini mengindikasikan bahwa model UTAUT yang digunakan dalam penelitian ini dapat diterima sebagai model penerimaan pengguna. Dari hasil pengujian menyimpulkan bahwa $\mathrm{H} 3$ ditolak, hal ini menunjukkan bahwa konstruk Social Influence (SI) tidak memiliki pengaruh terhadap kecendrungan pengguna untuk menggunakan sistem aplikasi (BI). Dapat dikatakan bahwa secara umum pengguna aplikasi perpustakan digital menggunakan sistem atas kesadaran sendiri, karena pengaruh dari orang lain atau pihak manajemen kurang memberikan kontribusi dalam kecendrungan pengguna dalam menggunakan aplikasi. $\mathrm{H} 1$ dan $\mathrm{H} 2$ diterima menunjukkan bahwa persepsi manfaat dari penggunaan aplikasi (PE) serta kemudahan menggunakan aplikasi (EE) memberikan pengaruh yang positif dalam niat pengguna untuk menggunakan aplikasi (BI).

Hal ini sesuai dengan hasil penelitian yang dilakukan Venkatesh (2003). Hipotesis 4 diterima yang berarti Facilitating Condition turut berpengaruh dalam menentukan pemakaian nyata dari aplikasi (AU). Ini menunjukkan perlunya fasilitas teknis yang mendukung bagi pengguna dalam menggunakan aplikasi. Infrastruktur seperti koneksi internet perlu diperhatikan, karen pada waktu-waktu tertentu koneksi internetnya masih lambat sehinggamempengaruhi pengguna dalam pemakaian aktualnya. Hipotesis 5 diterima, menunjukkan bahwa kecendrungan pengguna untuk menggunakan aplikasi (BI) berpengaruh secara langsung terhadap pemakaian aktual dari aplikasi (AU). Hal ini sesuai dengan hasil penelitian Venkatesh (2003) yang menyatakan bahwa niat atau kecendrungan untuk menggunakan aplikasi akan berpengaruh secara langsung terhadap pemakaian aktual dari aplikasi.

Pada hasil pengujian model penerimaan jurusan Manajemen dapat disimpulkan bahwa hipotesis 3 dan hipotesis 4 ditolak, hal ini menunjukkan bahwa pada model penerimaan jurusan manajemen konstruk social influence tidak memiliki pengaruh terhadap konstruk Behavioral Intention (BI) dan konstruk Facilitation Condition (FC) tidak berpengaruh terhadap konstruk Actual Usage (AU). Ini mengindikasikan bahwa pengguna dari jurusan manajemen dalam menggunakan aplikasi tidak dipengaruhi oleh orang lain ataupun pihak manajemen dan fasilitas internet untuk mengakses aplikasi dianggap sudah memadai karena dapat mengakes aplikasi setiap waktu. 
Pada hipotesis 1 dan hipotesis 2 diterima, ini menunjukkan bahwa pada jurusan manajemen konstruk BI dipengaruhi PE dan EE. Ini mengindikasikan bahwa pengguna dari jurusan manajemen cenderung untuk menggunakan aplikasi dikarenakan merasa ada manfaatnya dan mudah dalam pemakaiannya. Pada hipotesis 5 diterima, ini menunjukkan bahwa konstruk AU dipengaruhi oleh konstruk BI yang mengindikasikan bahwa ada niat keinginan pengguna dari jurusan manajemen dalam menggunakan dan memanfaatkan aplikasi.

Pada hasil pengujian model penerimaan jurusan Akuntansi dapat disimpulkan bahwa hipotesis 3 dan hipotesis 4 ditolak, hal ini menunjukkan bahwa pada model penerimaan jurusan Akuntansi konstruk social influence tidak memiliki pengaruh terhadap konstruk Behavioral Intention (BI) dan konstruk Facilitation Condition (FC) tidak berpengaruh terhadap konstruk Actual Usage (AU).

Hasil ini sama dengan jurusan Manajemen yang mengindikasikan bahwa pengguna dari jurusan Akuntansi dalam menggunakan aplikasi tidak dipengaruhi oleh orang lain ataupun pihak manajemen dan fasilitas internet untuk mengakses aplikasi dianggap sudah memadai karena dapat mengakes aplikasi sepanjang waktu. Pada hipotesis 1 dan hipotesis 2 dan hipotesis 5 diterima, ini menunjukkan bahwa pada jurusan Akuntansi konstruk $\mathrm{BI}$ dipengaruhi PE dan EE, serta konstruk AU dipengaruhi oleh konstruk BI. Ini mengindikasikan bahwa pengguna dari jurusan Akuntansi cenderung untuk menggunakan aplikasi karena merasa ada manfaatnya dan mudah dalam pemakaiannya, serta untuk hasil hipotesis 5 mengindikasikan bahwa ada niat keinginan pengguna dari jurusan manajemen dalam menggunakan dan memanfaatkan aplikasi.

Pada hasil pengujian model penerimaan jenis kelamin laki-laki sama dengan hasil model penerimaan jurusan manajemen dan akuntansi dengan kesimpulan bahwa hipotesis 3 dan hipotesis 4 ditolak, hal ini menunjukkan bahwa konstruk social influence tidak memiliki pengaruh terhadap konstruk Behavioral Intention (BI) dan konstruk Facilitation Condition (FC) tidak berpengaruh terhadap konstruk Actual Usage (AU). Ini mengindikasikan bahwa pengguna dari jenis kelamin laki-laki dalam menggunakan aplikasi tidak dipengaruhi oleh pihak lain dan fasilitas internet untuk mengakses aplikasi dianggap sudah memadai.

Pada hipotesis 1 dan hipotesis 2 dan hipotesis 5 diterima yang menunjukkan bahwa konstruk BI dipengaruhi PE dan EE, serta konstruk AU dipengaruhi oleh konstruk BI. Pada hasil ini menunjukkan aspek EE memiliki pengaruh sebesar 55\% yang mengindikasikan bahwa pengguna dari jenis kelamin laki-laki cenderung untuk menggunakan aplikasi karena kemudah dalam pemakaiannya. Hal ini berbeda dengan hasil penelitian Venkatesh (2003) yang menyatakan bahwa PE lebih menonjol pada laki-laki.

Pada hasil pengujian model penerimaan jenis kelamin perempuan hanya hipotesis 3 yang ditolak yang menunjukkan bahwa konstruk social influence tidak memiliki pengaruh terhadap konstruk Behavioral Intention (BI). Ini mengindikasikan bahwa pengguna dari jenis kelamin perempuan dalam menggunakan aplikasi tidak dipengaruhi oleh pihak lain atau pihak manajemen. Pada hipotesis 1, hipotesis 2, hipotesis 4, dan hipotesis 5 diterima dengan konstruk yang dominan adalah PE sebesar $42 \%$. Hal ini berbeda dengan penelitian Venkatesh (2003) yang menyatakan bahwa aspek kemudahan (EE) terhadap kecendrungan pengguna dalam menggunakan aplikasi lebih kuat pada gender perempuan. 
Analisis Faktor-Faktor...

Pada hasil pengujian model penerimaan dibawah umur 25 tahun hanya hipotesis 3 yang ditolak yang menunjukkan bahwa konstruk social influence tidak memiliki pengaruh terhadap konstruk Behavioral Intention (BI). Ini mengindikasikan bahwa pengguna dalam menggunakan aplikasi tidak dipengaruhi oleh pihak lain atau pihak manajemen. Pada hipotesis 1, hipotesis 2, hipotesis 4, dan hipotesis 5 diterima dengan konstruk yang berpengaruh adalah PE sebesar 29\% dan EE sebesar 49\%. Dapat disimpulkan bahwa aspek manfaat lebih berpengaruh dalam menggunakan aplikasi. Untuk itu, pihak manajemen harus lebih memperhatikan aspek kemudahan penggunaan aplikasi bagi mahasiswa dan dosen dengan menampung keluhan dan saran dalam rangka penyempurnaan aplikasi.

Pada hasil pengujian model penerimaan diatas umur 25 tahun hipotesis 3 dan hipotesis 4 ditolak yang menunjukkan bahwa konstruk Social Influence dan Facial Condition tidak memiliki pengaruh terhadap konstruk Behavioral Intention (BI). Ini mengindikasikan bahwa kecenderungan pengguna dari Dosen dalam menggunakan aplikasi tidak dipengaruhi oleh pihak lain atau pihak manajemen dan fasilitas internet dianggap sudah memadai. Pada hipotesis 1, hipotesis 2, dan hipotesis 5 diterima dengan konstruk yang berpengaruh adalah PE sebesar 33\% dan EE sebesar 30\%. Dapat disimpulkan bahwa aspek manfaat dan kemudahan berpengaruh dalam menggunakan aplikasi. Untuk itu, pihak manajemen harus lebih memperhatikan aspek manfaat penggunaan aplikasi dengan penambahan fitur-fitur dan modul-modul agar aplikasi dapat dikembangkan menjadi lebih baik lagi.

\section{KESIMPULAN DAN SARAN}

\subsection{Kesimpulan}

Berdasarkan hasil dari pengolahan pada penelitian ini dengan menggunakan modifikasi model UTAUT dan ADUTAUT, maka dapat disimpulkan bahwa secara umum faktor-faktor yang dapat mempengaruhi penerimaan pengguna aplikasi perpustakaan digital pada studi kasus Sekolah Tinggi IImu Ekonomi Indonesia Banking School adalah yaitu faktor PE (Performance Expectancy) kegunaan, faktor EE (Effort Expectancy) kemudahan mempengaruhi penguna dalam menggunakan aplikasi perpustakaan digital ini. Faktor FC (Facilitation Condition) kondisi fasilitas yang baik dapat mempengaruhi pengguna dalam menggunakan aplikasi dan faktor BI (Behavioral Intention) yaitu faktor kecenderungan niat pengguna yang mempengaruhi dalam menggunakan aplikasi.

Pada responden jurusan manajemen yang mempengaruhi penerimaan aplikasi perpustakaan digital adalah faktor kegunaan (Performance Expectancy), kemudahan (Effort Expectancy) yang menunjukkan penerimaan pengguna terhadap aplikasi perpustakaan digital Selain itu faktor BI (Behavioral Intention) menunjukkan dorongan niat menggunakan dan memanfaatkan layanan aplikasi perpustakaan digital. Tetapi lingkup jurusan ini tidak dipengaruhi oleh faktor SI (Social Influence) dan dorongan dari teman atau orang lain dan fasilitas FC (Facilitating Condition) untuk mengakses atau menggunakan aplikasi perpustakaan digital ini.

Hasil model jurusan Akuntansi yang mempengaruhi penerimaan aplikasi perpustakaan digital yaitu faktor kegunaan (Performance Expectancy) dan kemudahan (Effort Expectancy) serta dorongan niat menggunakan aplikasi perpustakaan digital oleh pengguna. Tetapi tidak dipengaruhi oleh faktor Social Influence dan Facilitating Condition. 
Hasil faktor-faktor yang mempengaruhi model pengguna laki-laki yaitu kegunaan (Performance Expectancy) dan kemudahan (Effort Expectancy). Faktor tersebut mengindikasikan bahwa pengguna menggunakan aplikasi perpustakaan digital dikarenakan kegunaan dan kemudahan aplikasi tersebut.

Hasil dari penelitian dengan asal responden dari pengguna perempuan berbeda dengan responden laki-laki. Faktor-faktor yang mempengaruhinya adalah PE (Performance Expectancy), EE (Effort Expectancy), dan FC (Facilitating Condition). Selain itu adanya faktor keinginan atau niat $\mathrm{BI}$ (Behavioral Intention) dari pengguna perempuan untuk menggunakan aplikasi perpustakaan digital.

Hasil dari penelitian dengan asal responden dari usia dibawah 25 tahun yaitu faktorfaktor yang mempengaruhi penerimaan aplikasi perpustakaan digital adalah faktor PE (Performance Expectancy), EE (Effort Expectancy), dan FC (Facilitating Condition), dan BI (Behavioral Intention). Faktor-faktor tersebut mengindikasikan bahwa pengguna usia dibawah 25 tahun menggunakan aplikasi karena faktor kegunaan dan kemudahan mengakses aplikasi perpustakaan digital tersebut.

Hasil dari penelitian dengan asal responden dari usia diatas 25 tahun berbeda dengan faktor-faktor yang mempengaruhi penerimaan aplikasi perpustakaan digital oleh pengguna usia diatas 25 tahun. Faktor-faktor yang mempengaruhi penggunaan aplikasi perpustakaan digital usia diatas 25 tahun adalah faktor PE (Performance Expectancy), EE (Effort Expectancy), dan BI (Behavioral Intention). Dimana faktor ini menunjukkan bahwa kegunaan dan kemudahan dapat mempengaruhi penggunaan untuk berniat menggunakan aplikasi perpustakaan digital.

\subsection{Saran}

Hasil dari kesimpulan sebelumnya menghasilkan faktor-faktor yang mempengaruhi tingkat penerimaan pengguna terhadap aplikasi perpustakaan digital, maka rekomendasi perbaikan pada aplikasi pada studi kasus perpustakan Sekolah IImu Ekonomi Indonesia Banking School tersebut yaitu:

a. Peningkatan kegunaan dari aplikasi perpustakaan digital dengan penambahan koleksi buku-buku digital, jurnal-jurnal elektronik, dan artikel elektronik yang berhubungan dengan jurusan manajemen dan akuntansi.

b. Peningkatan kemudahan aplikasi perpustakaan tersebut dengan penambahan multimedia dan gambar dari jenis kategori yang ditampilkan.

c. Peningkatan fasilitas infrastruktur dan penambahan kecepatan akses internet dan jaringan sehingga dapat mengakses aplikasi perpustakaan digital secara cepat baik akses secara lokal maupun dari luar lingkungan kampus.

Untuk kelanjutan penelitian ini kedepannya adalah melakukan penelitian lanjutan dengan mengkombinasikan penambahan moderator pengalaman untuk membuktikan bahwa lamanya pengalaman pengguna dalam menggunakan dan memanfaatkan aplikasi perpustakaan digital di suatu perguruan tinggi akan membuat pengaruh terhadap keinginan untuk menggunakan aplikasi tersebut. Selain itu penerapan aplikasi perpustakaan digital ini agar dapat diteliti kegunaan atau usability bagi tiap pengguna. 
Analisis Faktor-Faktor...

\section{DAFTAR PUSTAKA}

Biro Pusat Statistik (BPS) www.bps.go.id (dibuka pada 1 Desember 2012)

Davis, F.D. (1993), "User Acceptance of Information Technology: Characteristic System, User Perception and Behavioral Impacts.", International Journal of Man-Machine Studies, 38, pp 475-487.

Gary Cleveland, March 1998, "Digital Libraries: Definitions,Issues and Challenges", International Federation of Library Associations and Institutions, IFLA UDT Core Programme.

Gorecha, Anoop. (2005). "Application of The Unified Theory of Acceptance and Use of Technology to Internet Banking.", The University of Nottingham.

Greenstein Daniel and Thorin Suzanne E. (2002), "The Digital Library: A Biography", Digital Library Federation Council on Library and Information Resources Washington, D.C.

Hakim, Muhammad Malik. (2011). "Analisis Model Penerimaan Pengguna dengan Model UTAUT: Studi Kasus e-SPT dan e-Filing.", Universitas Indonesia, Karya Akhir.

Imam, Yuadi, (2009), "Analisis Technology Acceptance Model terhadap Perpustakaan Digital dengan Structural Equation Modeling", Departemen IImu Informasi dan Perpustakaan.

Juliansyah Noor, S.E., M.M., Dr. (2011),"Metodologi Penelitian”, Kencana Prenada Media Group.

Morteza Muthahhari (2011), "Kajian Tentang Penerimaan Pengguna Sistem Informasi Dengan Pendekatan UTAUT: Studi Kasus Universitas Islam Negeri Syarif Hidayatullah Jakarta", Universitas Indonesia, Karya Akhir

Orji, Rita Oluchi, (2010), "Effect of Academic Discipline on Tecnology Acceptance.", International Conference on Education and Manajemen Tecnology (ICEMT 2010).

Sekaran U. \& Roger Bougie, 2010, "Research Methodes for Business: A Skill Building Approach", A John Wiley and Sons, Ltd, Publication.

Setyo Hari Wijanto. (2008), "Structural Equation Modeling dengan Lisrel 8.8, Konsep dan Tutorial", Graha IImu.

Singgih Santoso dan Fandy Tjiptono,2002, "Riset Pemasaran: Konsep dan Aplikasi dengan SPSS", Elex Media Komputindo.

SLiMS (Senayan Library Management System). http://www.slims.web.id/web/ (diakses 16 Januari 2013)

Sulistyo-Basuki, 1991, "Pengantar IImu Perpustakaan",Gramedia Pustaka Utama.

Venkatesh, V., Morris, M. G., Davis, G. B., \& Davis, F. D. (2003). "User Acceptance of Information Technology: Toward a Unified View." MIS Quartely.

Wahono, 1998, "Perpustakaan Digital', Gramedia Pustaka Utama. 